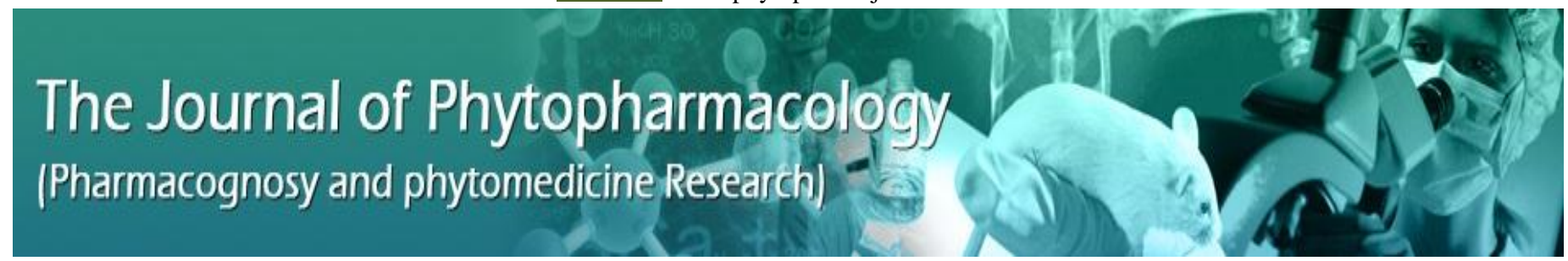

Research Article

ISSN 2230-480X

JPHYTO 2016; 5(2): 38-44

March- April

(c) 2016, All rights reserved

Dr. Poornima Solapure

Assistant Professor, Department of Dravyaguna, Sri Dharmasthala Manjunatheshwara (SDM) College of Ayurveda, Hassan, Karnataka, 573201, Indic

\section{Dr. Pradeep}

Associate Professor and Head, Department of Dravyaguna, Sri Dharmasthala Manjunatheshwara (SDM) College of Ayurveda, Hassan, Karnataka, 573201, India

\section{Mr. Ravi Mundugaru}

Research Officer, Department of Pharmacology and Toxicology, SDM Centre for Research in Ayurveda and Allied Sciences, Udupi, Karnataka-574118, India

Dr. Prakash L Hegde

Professor, Department of Dravyaguna, Sri Dharmasthala Manjunatheshwara (SDM) College of Ayurveda, Hassan, Karnataka, 573201, India

\section{Correspondence:}

Dr. Poornima Solapure

Assistant Professor, Department of Dravyaguna, Sri Dharmasthala Manjunatheshwara (SDM) College of Ayurveda, Hassan, Karnataka, 573201, India

Email:drpoornimabs5[at]gmail.com

\section{Comparative anti-inflammatory activity of Clerodendrum serratum (Linn) Moon and Solanum xanthocarpum Schrad and Wendl in wistar ablino rats}

\author{
Poornima Solapure*, Pradeep, Ravi Mundugaru, Prakash L Hegde
}

\section{ABSTRACT}

C. serratum and S. xanthocarpum plants are used as folk remedies for inflammations, arthritis, cough, asthma and bronchitis. The present investigation aimed to evaluate the comparative anti-inflammatory activity in Wistar albino rats. The group specific rats were treated for seven consecutive days and subjected to carrageenan induced paw oedema and cotton pellet implanted granuloma tissue formation tests at a dose of $8.64 \mathrm{ml} / \mathrm{kg}$ (p.o). Both the test drugs have shown reduced paw volume during third and sixth hour readings and a moderate decrease in the granuloma tissue formation. CRP enzyme was found to be reduced significantly and a moderate elevation in white pulp of spleen from both the test groups were observed. The present findings suggest that both the drugs have moderate anti-inflammatory activity as ascertained by the comparative decrease in carrageenan induced paw volume, decreased granuloma tissue formation and normal histological profile of important organs.

Keywords: Anti-inflammation, Clerodendrum serratum, Solanum xanthocarpum, Carrageenan, Cotton pellet, CRP.

\section{INTRODUCTION}

Clerodendrum serratum (Linn.) Moon [C. serratum] which belongs to the family Verbenaceae, is a shrub distributed throughout India, Ceylon, Malaya and Peninsular regions. Root of the plant has a pungent, bitter, acrid taste; used in the treatment for inflammations, asthma, bronchitis, hiccough conditions. ${ }^{1}$ Scientific evaluation on $C$. serratum has revealed many pharmacological activities such as hepatoprotective, antinociceptive, anti-inflammatory, antipyretic and analgesic effects. ${ }^{2-4}$ The phytochemical analysis has been reported with the presence of alkaloids, flavonoids, glycosides, saponins and sterols as the in the plant. ${ }^{5}$

Solanum xanthocarpum Schrad. and Wendl [S. xanthocarpum] is a very prickly diffused bright-green, perennial herb of the family Solanaceae. ${ }^{6}$ It is found abundantly grown throughout India in plains of dry regions, by roadsides, wastelands and rubbish heaps. ${ }^{7}$ The wide distribution of this plant species is also found in Ceylon, South-east Asia, Malaysia and Tropical Australia. Root is pungent, bitter; indicated in asthma, bronchitis, cough, fever and various other ailments in folklore practice. ${ }^{6}$ Alkaloids, sterols, saponins, flavonoids and glycosides are the reported phytoconstituents ${ }^{8}$ and the plant has been evaluated for its immuno-modulatory, hypoglycaemic, hepatoprotective, nephroprotective activities. ${ }^{9-12}$

Inflammation is a protective host response intended to eliminate the initial cause of cell injury as well as the necrotic cells and tissues resulting from the original insult. On one hand the inflammatory process helps to clear infections, noxious stimuli, initiates repair; the reaction and the subsequent repair process can cause considerable harm on the other. ${ }^{13}$ Thus, it becomes the cause of injury and disease when it is not adequately controlled. Inflammation may contribute to a variety of diseases that are not thought to be primarily due to abnormal host responses. ${ }^{14}$ A comprehensive list of inflammatory diseases would run to over hundred, each of which has high levels of inflammatory reactions in the connective tissues, or degeneration of these tissues such as ankylosis, spondylitis, osteoarthritis, rheumatoid arthritis, asthma, atherosclerosis, dermatitis, irritable bowel syndrome (IBS), systemic lupus erythematous (SLE), nephritis, ulcerative colitis and to enlist many such conditions.

A concept was established that chemical substances such as histamine mediate the vascular changes of inflammation (By Sir Thomas Lewis while studying the inflammatory response in skin). This fundamental concept underlies the important discoveries of chemical mediators of inflammation and the use of anti-inflammatory drugs in clinical medicine. ${ }^{14}$ 
Non steroidal anti-inflammatory drugs (NSAIDs) are the commonly prescribed drugs for many inflammatory conditions worldwide. The anti-inflammatory actions of the NSAIDs are most likely explained by their inhibition of prostaglandin synthesis by the enzyme cyclooxygenase (COX) during inflammatory processes. It is found that there is no one NSAIDs empirically superior for the treatment of inflammatory diseases; instead, each individual's response to and tolerance of a drug determines its therapeutic utility. The ability of NSAIDs to increase gastric acid secretion and inhibit blood clotting can lead to peptic ulceration, iron deficiency anaemia, gastrointestinal blood loss and several other adverse effects. ${ }^{15}$

Plants are natural reservoirs of several phytoconstituents which possess many therapeutic values with minimum adverse effects. Phytochemical constituents such as alkaloids, flavonoids, glycosides, saponins, steroids are found in medicinal plants and are responsible for their therapeutic action ${ }^{16}$. There is a continuous search for potent, much better efficacious and with minimum adverse effect antiinflammatory herbal drugs. $C$. serratum and $S$. xanthocarpum are such plant origin drugs which are attributed with the potentiality of antiinflammatory effect asserted by the pioneers of Ayurveda. ${ }^{17,18}$ Hence, the present study was carried out to compare the anti-inflammatory activity possessed by two plants.

\section{MATERIALS AND METHODS}

\section{Chemical material}

Carrageenan [batch number RM 1576-100 G was obtained from HiMedia Laboratories Pvt. Limited, Mumbai, Maharashtra, India].

Carboxymethyl cellulose [batch number QF1Q610371 was obtained from Merck Specialities Private Limited, Mumbai, Maharashtra, India].

\section{Plant material}

The root parts of the plants, $C$. serratum and $S$. xanthocarpum were collected from their natural habitat of Belgaum, Karnataka, India during March - April, 2014. Their authentication was confirmed at the Department of Dravyaguna, Shri Dharmasthala Manjunatheshwara College of Ayurveda and Hospital, Hassan, Karnataka, India. The obtained roots were air-dried under sunlight for two consecutive weeks. The dried plant material was later coarsely ground in a pulveriser and stored in plastic air tight containers for further experimentation.

\section{Preparation of decoction}

The decoction of roots of $C$. serratum and $S$. xanthocarpum was prepared at the Department of Rasashastra and Bhaishajya Kalpana, SDMCA, Udupi, Karnataka, India as per the classical reference described in Sharangadhara Samhita, Madhyamakhanda, Kwathakalpana of Ayurveda. ${ }^{19}$

\section{Experimental animals}

Wistar albino rats weighing $150 \pm 50 \mathrm{~g}$ body weight of either sex were obtained from animal house attached to the department of Pharmacology, SDM Research Centre, Udupi, Karnataka, India. The experimental protocol was approved by the institutional animal ethical committee under the reference no. SDMCAU/IAEC/2014-15 HSD-02. Animals were kept in poly propylene cages under naturally illuminated environment of 12:12h light and dark cycle, temperature of $25^{\circ} \mathrm{C}$ and relative humidity of approximately $50 \%$. They were fed with rat diet and had access to tap water ad libitum throughout the study.

\section{Anti inflammatory activity}

\section{Acute anti inflammatory activity}

Animals were divided into four groups of six animals each. The first group (control group) received normal tap water $(5 \mathrm{ml} / \mathrm{kg}, \mathrm{p} . \mathrm{o})$, second group (standard group) was administered diclofenac sodium $(5 \mathrm{mg} / \mathrm{kg}$, p.o), third group (Test drug I) was administered with decoction of $C$. serratum and group IV (Test drug II) with root decoction of $S$. xanthocarpum at a dose of $8.64 \mathrm{ml} / \mathrm{kg}$ body weight of the rat p.o respectively. Winter et al (1962) method was followed to assess the anti inflammatory effect of test drugs via testing its ability to inhibit carrageenan induced paw edema in rats during acute phase of inflammation. ${ }^{20}$ The group specific drugs were administered orally for seven consecutive days and on seventh day one hour after drug administration the acute inflammation was produced by injecting 0.1 $\mathrm{ml}$ of $1 \%$ carrageenan solution into sub plantar surface of rat's hind paw. The paw volume up to the tibio-tarsal articulation was measured using a Plethysmometer (PLM-01 PLUS Orchid Scientifics) at basal, $1^{\text {st }}$ hour, $3^{\text {rd }}$ hour and $6^{\text {th }}$ hour after carrageenan injection. The antiinflammatory activity was expressed as percentage inhibition of paw edema using the formula: $\mathrm{V}_{\mathrm{c}}-\mathrm{V}_{\mathrm{t}} / \mathrm{V}_{\mathrm{c}} \mathrm{X} 100$, where $\mathrm{V}_{\mathrm{c}}$ is the paw volume of control group and $\mathrm{V}_{\mathrm{t}}$ being the paw volume of test group.

\section{Cotton pellet implanted granuloma method}

Animals were grouped into four different categories, comprising six rats in each group. The first group was fed with normal tap water (5ml/kg, p.o), second group (standard group) was administered with ibuprofen $(100 \mathrm{mg} / \mathrm{kg}, \mathrm{p} . \mathrm{o})$ and the test groups were administered with root decoction of $C$. serratum and $S$. xanthocarpum $(8.64 \mathrm{ml} / \mathrm{kg}, \mathrm{p} . \mathrm{o})$ respectively.

The effect of test drugs on cotton pellet implanted granuloma formation in rats was assessed as per the method described by Meier et al $(1950)^{21}$. The rats were anaesthetised under ketamine $(80 \mathrm{mg} / \mathrm{kg}$, i.p). The dorsum was shaved and swabbed with $70 \%(\mathrm{v} / \mathrm{v})$ alcohol. Mid-line incision of $1 \mathrm{~cm}$ was made in the intrascapular region and a small tunnel was made on either side of the incision with the help of small blunt forceps. One sterile cotton pellet weighing $100 \mathrm{mg}$ (prepared by rolling of a cotton piece of $100 \mathrm{mg}$ and sterilised by autoclaving for $30 \mathrm{~min}$ under $15 \mathrm{lbs}$ pressure) was inserted per tunnel and the incision was closed with interrupted sutures after expelling the air from the tunnel. Group specific drugs were administered for seven consecutive days starting from the day of implantation. The rats were sacrificed on 8th day and dissected for collection of organs viz. thymus, spleen and adrenal glands. Implanted cotton pellets were removed and cleaned of extraneous tissues and dried by placing them in a hot air oven overnight at $80^{\circ} \mathrm{C}$ and then weighed. The difference between the initial weight and the final weight of the pellets after drying was taken as the weight of granuloma tissue. The result was expressed as $\mathrm{mg}$ of granulation tissue formed per $100 \mathrm{~g}$ body weight of the rat. The weight of spleen and thymus were noted. The dissected organs were preserved in 10\% formalin and sent for histopathological examination. In addition, blood was withdrawn from retro- orbital plexus with the help of capillary tubes and the samples were collected to estimate biochemical parameters.

\section{Statistical analysis}

The experimental data were expressed as mean \pm standard error mean. The data obtained was analysed by using one way analysis of variance (ANOVA) followed by Dunnett's multiple ' $t$ ' test for determining the level of significance of the observed effects. A ' $p$ ' value of less than 0.05 was considered statistically significant. Graph Pad In Stat-3 was used for statistical analysis of the generated data. 


\section{RESULT}

\section{Carrageenan induced paw edema}

During third hour of observation, the test drug $C$. serratum administered group has shown significant decrease in the percentage change in paw volume while the standard drug and test drug $S$. xanthocarpum administered groups did not show significant suppression of paw volume when compared with that of control group. During sixth hour of observation both the test groups and standard group have shown statistically insignificant decrease in the percentage inhibition of paw volume in comparison to control group (Table 1).

\section{Cotton pellet implanted granuloma}

An apparent modest decrease in granulation tissue formation was observed in both standard and test drug administered groups. However, the observed changes were statistically insignificant with that of control group. Both the test drug administered groups have shown moderate decrease in the weight of the spleen in comparison to normal control group. Increase in the weight of thymus was observed in both the test drug groups, but, was significant only in the drug $S$. xanthocarpum when compared with the control group. Test drugs have shown mild to moderate changes of liver enzymes such as SGOT, SGPT and ALP in comparison to normal control group and it is found to be statistically insignificant. Serum CRP, serum urea and serum creatinine were found to be significantly decreased in both the test groups. Although moderate increase was observed in white pulp proportion of spleen in both the groups of test drugs it was less in comparison to normal control group. The sections of thymus and adrenal gland from both the test groups exhibited normal cytoarchitecture when compared with the normal control group (Table 2-5 and Figure 1-3).

\section{DISCUSSION}

Carrageenan induced hind paw edema test is based on the principle of release of various inflammatory mediators by carrageenan. ${ }^{22}$ The test is selected because of its sensitivity in evaluating orally active antiinflammatory drugs particularly in acute phase of inflammation. ${ }^{23}$ Edema formation due to carrageenan in the rat paw is biphasic, where in the first phase begins immediately after injection of carrageenan with the release of histamine, serotonin and kinins from local tissue damage and act on the vascular permeability lasting up to two hours. The second phase begins at the end of first phase and is due to the release of prostaglandins, protease and lysosomes by tissue macrophages after 3rd hour of tissue damage and lasts for duration of three to six hours. ${ }^{22}$ Subcutaneous injection of carrageenan into the rat paw produces inflammation resulting from plasma extravasation, increased tissue water and plasma protein exudation, along with neutrophils extravasation, due to the metabolism of arachidonic acid. ${ }^{23}$ From the results, it is observed that the test drug $C$. serratum has significant anti -inflammatory activity in the early phase of inflammatory process which might be due to inhibition of early release of histamines, serotonins and prostaglandins from the damaged tissue while in the later phase of inflammation both the test drugs have shown mild to moderate activity which indicated their weak potency to inhibit the release of inflammatory mediators such as prostaglandins and leukotrienes from tissue macrophages.

Cotton pellet implanted granuloma model is based on the foreign body granuloma that can provoke by subcutaneous implantation of pellets of compressed cotton in rats. The method has been widely used to assess the three phases of chronic inflammation, which are: a transudative phase, defined as the increase in the wet weight of the pellet that occurs during the first 3 hours; an exudative phase, defined as plasma leaking from the blood stream around the granuloma that occurs between 3 hours and 72 hours after the implantation of pellet and a proliferative phase, measured as the increase in the dry weight of the granuloma that occurs between 3 and 6 days after the implantation and thus to evaluate the anti-proliferative effect of drugs. ${ }^{24}$ The cotton pellets implanted in the intrascapular region induces a chronic inflammation process in which development of proliferative cells, monocyte migration, liquid accumulation, apoptosis, damage and so on will occur in the surrounding tissue of the pellets and these accumulations will produce a granulation tissue that covers the pellets. The anti-proliferative effect of antiinflammatory drugs is due to prevention of collagen fibre formation and suppression of mucopolysaccharides. ${ }^{25}$ From the critical analysis of results, the two test drugs have shown slight decrease in the granulomatous tissue in comparison to normal control group. Test drug $C$. serratum has produced slightly better effect by reducing the granulomatous tissue when compared to test drug $S$. xanthocarpum. Thus, the probable mode of action of the test drugs may be due to the weak anti-proliferative effect by preventing the formation of collagen fibre and suppressing mucopolysaccharides.

The results related to the ponderal changes of spleen and thymus organs were found to be comparable with that of normal control group. However test drug S. xanthocarpum which showed increased thymus weight might be due to the hyperactivity during chronic inflammation.

Anti-inflammatory drugs sometime produce decrease in the activity of SGOT and SGPT enzymes by decreasing the biogenic amine formation which contributes to anti inflammatory effect. In this study, the results related to the above two parameters did not show any marked changes. However, the test groups have shown significant elevation which may be due to non-specific induction of liver enzymes and the mechanism does not seem to be involved in the effect observed with the test drugs.

Arachidonic acid metabolites can mediate the inflow of leucocytes into inflammatory sites leading to tissue damage by releasing lysosomal enzymes and toxic oxygen radicals. The activity of lysosomal enzymes, such as raised alkaline phosphatase in serum during the inflammatory process results in damage to the tissue and cartilage that can lead to perpetuate the inflammation further. ${ }^{24}$ The serum alkaline phosphatase is elevated during cotton pellet granuloma formation. This elevated lysosomal enzyme activity in serum and exudate during inflammation can be normalized by stabilizing the lysosomal membrane during chronic inflammation. From the results obtained, the two test groups have shown considerable increase in serum ALP level. However test drug test drug C. serratum has shown slightly more increase in serum ALP level when compared to test drug $S$. xanthocarpum. Thus, both the test drugs have failed to reduce the elevated lysosomal activity and exudate during chronic inflammation.

Serum CRP is a specific abnormal protein that appears in the blood in response to inflammatory cytokines such as interleukin-6 (IL-6) during an inflammatory process. It is one of the most sensitive acute phase reactants. CRP levels in the body have been used as a marker or indicator of inflammation. ${ }^{26}$ From the critical analysis of the results, the two test drugs have shown significant decrease in serum CRP level. However test drug $S$. xanthocarpum has shown better effect than test drug $C$. serratum. This is indicative of inflammation reducing potential of both the drugs.

Elevation in the levels of serum urea and creatinine is indicative of altered kidney function. The decrease may be indicative of decrease in their formation. Urea decrease is indicative of decreased nitrogen turn over and creatinine decrease may be due to decreased muscular activity or decreased formation in the liver. The results related to the serum biochemical parameters such as serum urea and serum creatinine did not show any marked changes. However, the test groups have shown significant reduction in comparison to normal control group. Thus, the alteration in these two parameters has no linkage with the anti inflammatory activity observed against chronic inflammation. 
Table 1: Effect of test drugs in carrageenan induced paw oedema test

\begin{tabular}{|c|c|c|c|c|c|c|c|c|}
\hline \multirow[t]{2}{*}{ Group } & \multirow[t]{2}{*}{ Dose } & \multicolumn{7}{|c|}{ Percentage change in Carrageenan induced paw oedema $(\mathrm{ml})$} \\
\hline & & Basal & $1 \mathrm{~h}$ & $\%$ change & $3 \mathbf{h}$ & $\%$ change & $6 \mathbf{h}$ & $\%$ change \\
\hline Normal control & $1 / \mathrm{kg}$ & $0.85 \pm 0.03$ & $14.20 \pm 1.93$ & - & $34.32 \pm 5.27$ & - & $9.72 \pm 3.16$ & - \\
\hline Diclofenac sodium & $\mathrm{g} / \mathrm{kg}$ & $0.84 \pm 0.03$ & $18.05 \pm 4.01$ & $27 \uparrow$ & $30.33 \pm 6.77$ & $11.62 \downarrow$ & $8.15 \pm 3.91$ & $16.15 \downarrow$ \\
\hline C.serratum & $4 \mathrm{ml} / \mathrm{kg}$ & $0.90 \pm 0.03$ & $17.24 \pm 4.54$ & $21 \uparrow$ & $11.24 \pm 4.91 *$ & $67.24 \downarrow$ & $11.60 \pm 5.16$ & $19.34 \uparrow$ \\
\hline S. xanthocarpum & $4 \mathrm{ml} / \mathrm{kg}$ & $0.92 \pm 0.02$ & $19.31 \pm 6.44$ & $35 \uparrow$ & $29.95 \pm 4.03$ & $12.73 \downarrow$ & $15.43 \pm 4.44$ & $58.74 \uparrow$ \\
\hline
\end{tabular}

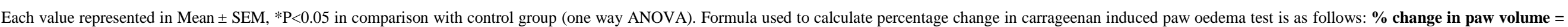
Ve- Vt Ve X 100 (Vc-Paw volume of control group, $\mathrm{Vt}$ - Paw volume of test group)

Table 2: Effect of test drugs in cotton pellet implanted granuloma tissue formation test

\begin{tabular}{lcc}
\hline Group & Dose & Granuloma tissue weight (grams) \\
\hline Normal control & $5 \mathrm{ml} / \mathrm{kg}$ & $35.13 \pm 0.76$ \\
Ibuprofen & $100 \mathrm{mg} / \mathrm{kg}$ & $31.42 \pm 1.88$ \\
C.serratum & $8.64 \mathrm{ml} / \mathrm{kg}$ & $32.89 \pm 2.23$ \\
S. xanthocarpum & $8.64 \mathrm{ml} / \mathrm{kg}$ & $33.48 \pm 2.75$ \\
\hline
\end{tabular}

Each value represented in Mean \pm SEM in comparison with control group (one way ANOVA).

Table 3: Effect of test drugs on weights of spleen and thymus in cotton pellet implanted granuloma tissue formation test

\begin{tabular}{|c|c|c|c|c|}
\hline \multirow[b]{2}{*}{ Group } & \multicolumn{3}{|c|}{ \% change } & \multirow[t]{2}{*}{$\%$ change } \\
\hline & Spleen weight (g) & & Thymus weight (g) & \\
\hline $\begin{array}{l}\text { Normal control } \\
(5 \mathrm{ml} / \mathrm{kg})\end{array}$ & $0.63 \pm 0.06$ & - & $0.42 \pm 0.04$ & - \\
\hline $\begin{array}{l}\text { Ibuprofen } \\
(100 \mathrm{mg} / \mathrm{kg})\end{array}$ & $0.77 \pm 0.11$ & $22.36 \uparrow$ & $0.35 \pm 0.02$ & $17.24 \downarrow$ \\
\hline $\begin{array}{l}\text { C.serratum } \\
(8.64 \mathrm{ml} / \mathrm{kg})\end{array}$ & $0.42 \pm 0.04$ & $33.38 \downarrow$ & $0.59 \pm 0.05$ & $38.22 \uparrow$ \\
\hline $\begin{array}{l}\text { S. xanthocarpum } \\
(8.64 \mathrm{ml} / \mathrm{kg})\end{array}$ & $0.53 \pm 0.09$ & $16.53 \downarrow$ & $0.76 \pm 0.08 * *$ & $77.85 \uparrow$ \\
\hline
\end{tabular}

Each value represented in Mean $\pm \mathrm{SEM}, * * \mathrm{P}<0.01$ in comparison with control group (one way ANOVA). 
Table 4: Effect of test drugs on SGOT, SGPT, ALP activity in cotton pellet implanted granuloma tissue formation test

\begin{tabular}{|c|c|c|c|c|c|c|}
\hline Group & $\begin{array}{l}\text { SGOT } \\
\text { (unit/l) }\end{array}$ & $\%$ change & $\begin{array}{l}\text { SGPT } \\
\text { (unit/l) }\end{array}$ & $\%$ change & $\begin{array}{l}\text { ALP } \\
\text { (unit/dl) }\end{array}$ & $\%$ change \\
\hline $\begin{array}{l}\text { Normal control } \\
(5 \mathrm{ml} / \mathrm{kg})\end{array}$ & $199.4 \pm 6.80$ & - & $54.8 \pm 6.92$ & - & $293.8 \pm 16.47$ & - \\
\hline $\begin{array}{l}\text { Ibuprofen } \\
(100 \mathrm{mg} / \mathrm{kg})\end{array}$ & $190.5 \pm 11.56$ & $4.46 \downarrow$ & $80.16 \pm 6.78^{*}$ & $46.27 \uparrow$ & $239.83 \pm 17.12$ & $18.36 \downarrow$ \\
\hline $\begin{array}{l}\text { C.serratum } \\
(8.64 \mathrm{ml} / \mathrm{kg})\end{array}$ & $174 \pm 11.10$ & $12.73 \downarrow$ & $60.83 \pm 4.76$ & $11.00 \uparrow$ & $651.4 \pm 52.17 * *$ & $121.7 \uparrow$ \\
\hline $\begin{array}{l}\text { S. xanthocarpum } \\
(8.64 \mathrm{ml} / \mathrm{kg})\end{array}$ & $208.83 \pm 17.13$ & $4.72 \uparrow$ & $66.66 \pm 3.73$ & $21.64 \uparrow$ & $517.33 \pm 95.78^{*}$ & $76.08 \uparrow$ \\
\hline
\end{tabular}

Each value represented in Mean $\pm \mathrm{SEM}, * \mathrm{P}<0.05, * * \mathrm{P}<0.01$ in comparison with control group (one way ANOVA).

Table 5: Effect of test drugs on CRP, serum urea, serum creatinine activity in cotton pellet implanted granuloma tissue formation test

\begin{tabular}{|c|c|c|c|c|c|c|}
\hline Group & $\begin{array}{l}\text { CRP } \\
(\mathrm{mg} / \mathrm{l})\end{array}$ & $\%$ change & $\begin{array}{l}\text { Serum urea } \\
(\mathrm{mg} / \mathrm{dl})\end{array}$ & $\%$ change & $\begin{array}{l}\text { Serum creatinine } \\
\text { (mg/dl) }\end{array}$ & $\begin{array}{c}\% \\
\text { change }\end{array}$ \\
\hline $\begin{array}{l}\text { Normal control } \\
(5 \mathrm{ml} / \mathrm{kg})\end{array}$ & $0.95 \pm 0.09$ & - & $55.65 \pm 6.19$ & - & $0.71 \pm 0.04$ & - \\
\hline $\begin{array}{l}\text { Ibuprofen } \\
(100 \mathrm{mg} / \mathrm{kg})\end{array}$ & $0.93 \pm 0.01$ & $2.19 \downarrow$ & $41.5 \pm 5.43$ & $25.42 \downarrow$ & $0.55 \pm 0.03 *$ & $22.53 \downarrow$ \\
\hline $\begin{array}{l}\text { C.serratum } \\
(8.64 \mathrm{ml} / \mathrm{kg})\end{array}$ & $0.56 \pm 0.04 * *$ & $40.79 \downarrow$ & $30.41 \pm 1.45 * *$ & $43.35 \downarrow$ & $0.53 \pm 0.02 * *$ & $47 \downarrow$ \\
\hline $\begin{array}{l}\text { S. xanthocarpum } \\
(8.64 \mathrm{ml} / \mathrm{kg})\end{array}$ & $0.67 \pm 0.06 * *$ & $29.81 \downarrow$ & $35.73 \pm 1.33 * *$ & $35.79 \downarrow$ & $0.50 \pm 0.04 * *$ & $29.57 \downarrow$ \\
\hline
\end{tabular}

Each value represented in Mean $\pm \mathrm{SEM}, * \mathrm{P}<0.05, * * \mathrm{P}<0.01$ in comparison with control group (one way ANOVA). 

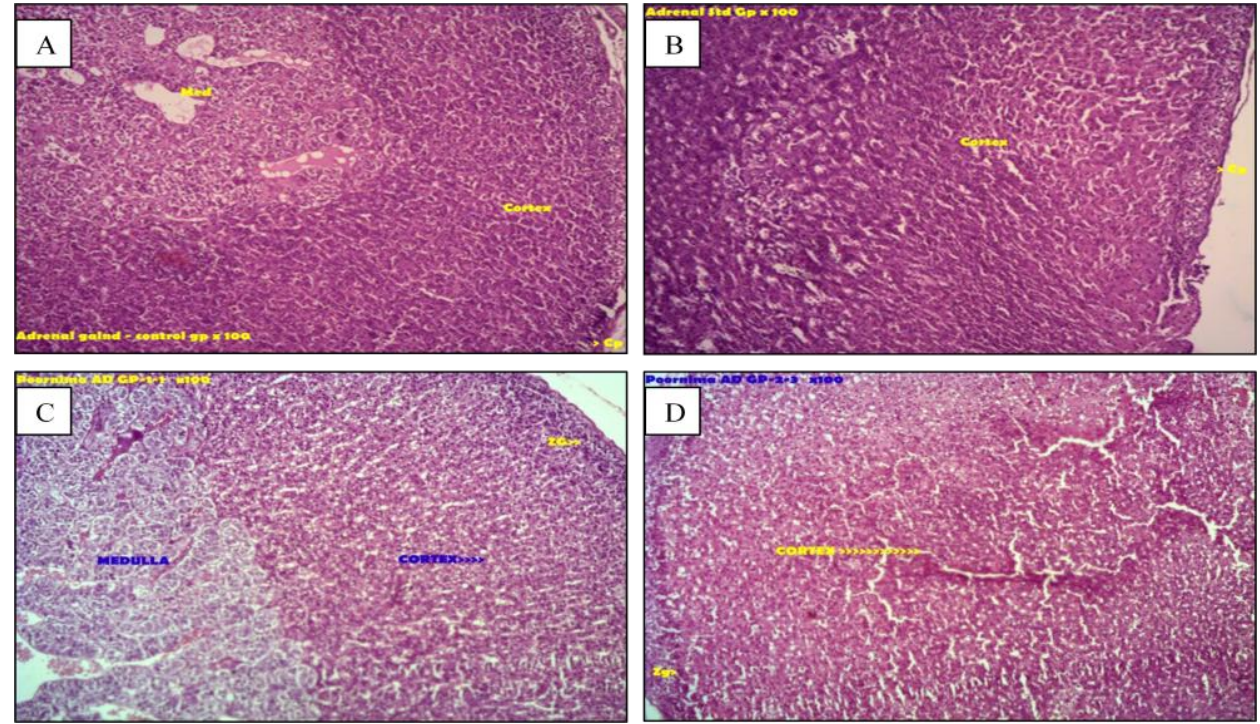

Figure 1: Histology of adrenal glands; A-Control group, B- Standard group, C- Test group I, D- Test group II, $\mathrm{Cp}$ - capsule, $\mathrm{Zg}$ - zona glomerulosa, Med - medulla, Cortex
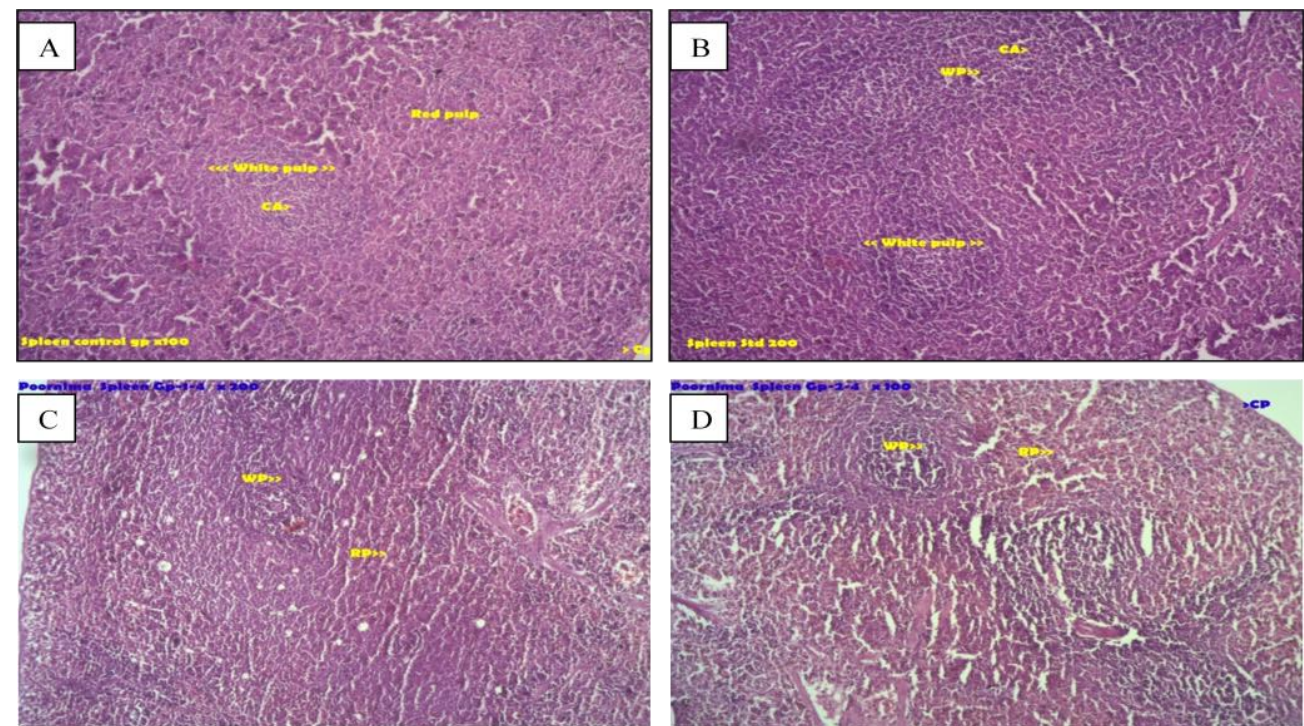

Figure 2: Histology of spleen; A-Control group, B- Standard group, C- Test group I, D- Test group II, CA- Central artery, Cp - capsule, WP- white pulp, RP- Red pulp
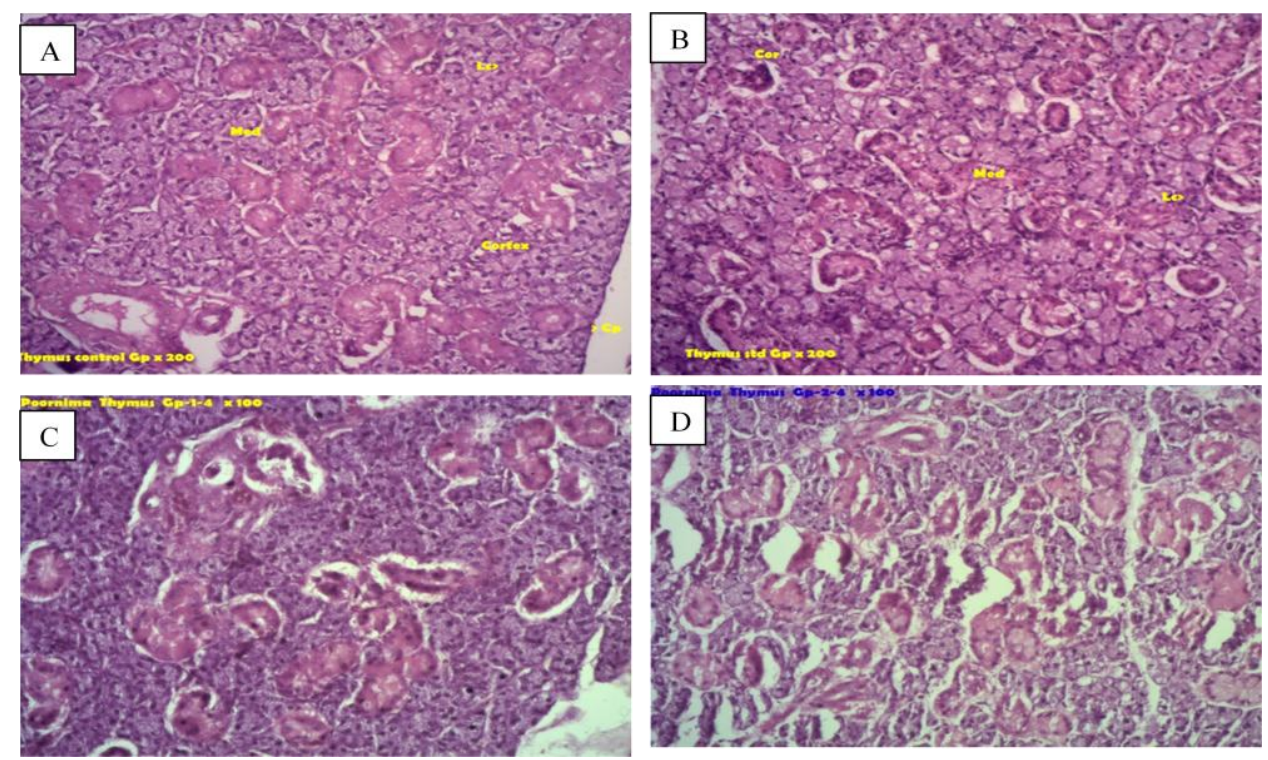

Figure 3: Histology of thymus; A-Control group, B- Standard group, C- Test group I, D- Test group II, Cor- Cortex, Cp - capsule, Lc- lobule, Med - medulla 
In chronic inflammatory reaction, the accumulation of lymphocytes, antigen presenting cells and plasma cells may assume the morphologic features of lymphoid organs like spleen and thymus. The results of histopathological examination revealed that there was increase in the white pulp proportion of spleen in both the test drug administered groups and no remarkable changes were found in cytoarchitecture in the sections of thymus as well. This is indicative of lesser magnitude of inflammation seen in both the test groups. The sections of adrenal gland obtained from both test groups exhibited normal cytoarchitecture which indicated the stimulation of adrenal cortex.

\section{CONCLUSION}

In carrageenan induced paw edema test $C$. serratum has shown significant suppression of edema while $S$. xanthocarpum produced weak effect. Both the test drugs have produced weak antiinflammatory effect in cotton pellet implanted granuloma model for chronic inflammation. Thus, this experimental study rules out any significant difference in both the test drugs as they have shown similar anti-inflammatory effect. This opens up a new avenue for further study of phytomedicines exhibiting anti-inflammatory potentials and render scope for their therapeutic usage in several inflammatory mediated diseases.

\section{Acknowledgement}

The authors offer their humble gratitudes to Dr Veerendra Heggade, President, S.D.M Education Society, Ujire, Karnataka, India; Dr Prasanna N Rao, Principal, S.D.M.College of Ayurveda, Hassan, Karnataka, India; Dr B Ravishankar, Director, S.D.M Centre for Research in Ayurveda and Allied Sciences, Udupi, Karnataka, India; Dr Harini A, Dr Poornima B and Dr Anuradha K N, Department of Dravyaguna, S.D.M.College of Ayurveda, Hassan, Karnataka, India; Mr Sudhakar, S.D.M Centre for Research in Ayurveda and Allied Sciences, Udupi, Karnataka, India; Dr Mallika K J and Girish K J, S.D.M.College of Ayurveda, Hassan, Karnataka, India for their constant support and guidance.

\section{REFERENCES}

1. Basu K R, Basu B D. Indian Medicinal Plants. Vol III. 2nd ed. International Book Distributors, Dehradun, 1987, pp 1948.

2. Vaidya S M Krishna, V, Manjunatha B K, Mankani KL, Ahmed, Jagadeesha S D. Evaluation of Hepatoprotective activity of Clerodendrum serratum L. Indian Journal of Experimental Biology. 2007; 45:538-542.

3. Narayanan N, Thirugnanasambantham P. Antinociceptive, antiinflammatory and antipyretic effects of ethanol extract of Clerodendron serratum roots in experimental animals. Journal of Ethnopharmacology. 1999; 65: 237-241.

4. Saha et al. Evaluation of analgesic activity of ethanolic extract of Clerodendrum serratum Linn leaves in rats. International Research Journal of Pharmaceutical and Applied Sciences. 2012; 2: 33-37.

5. Gupta AK, Tandon N, Sharma M. Review on Indian Medicinal Plants. Vol VII. Indian Council of Medical Research, New Delhi,2008, pp 110111.

6. Basu K R, Basu B D. Indian Medicinal Plants. Vol III. 2nd ed. International Book Distributors, Dehradun, 1987, pp 1759-60.

7. Tandon N, Sharma M. Quality Standard of Indian Medicinal Plants. Vol VIII. Indian Concil of Medical Research, New Delhi, 2010,pp 283.

8. Singh Om, Singh T P. Phytochemistry of Solanum xanthocarpum: an amazing traditional healer. Journal of Scientific and Industrial Research. 2010; 69:732-740

9. Rokeya Sultana, Salma Khanam, Kshama Devi. Immunomodulatory effect of methanolextract of Solanum xanthocarpum fruits. International Journal of Pharma Sciences and Research. 2011; 2 : 93-97.

10. Kar D M, Maharana L, Pattnaik S, Dash G K. Studies on hypoglycaemic activity of Solanum xanthocarpum Schrad. \& Wendl. fruit extract in rats. Journal of Ethnopharmacology. 2006; 108: 251-256.

11. Ramesh K Gupta, Talib Hussain, G. Panigrahi, Avik Das, Gireesh Narayan Singh. Hepatoprotective effect of Solanum xanthocarpum fruit extract against $\mathrm{CCl} 4$ induced acute liver toxicity in experimental animals. Asian Pacific Journal of Tropical Medicine. 2011; 4: 964-968.
12. Talib Hussain, Ramesh K Gupta, K Sweety, Bavani Eswaran, Vijaya Kumar. Nephroprotective activity of Solanum xanthocarpum fruit extract against gentamicin-induced nephrotoxicity and renal dysfunction in experimental rodents. Asian Pacific Journal of Tropical Medicine. 2012; 5:, 686-691.

13. Kumar V, Abbas AK, Fausto N, Mitchell R. Robbins. Basic Pathology.8th ed. Elsevier, 2007, pp 31.

14. Kumar V, Abbas AK, Fausto N, Aster JC. Robins and Cotran Pathologic Basis of Disease. 8thed. Elsevier, 2010, pp 44.

15. Craig C, Stitzel R. Modern Pharmacology with Clinical Applications. 6th ed. Lippinciott Williams \& Wilkins, pp 427.

16. Inflammation: the foundation of diseases and disorders. (2007). A review of phytomedicines of South African origin used to treat pain and inflammatory conditions. African Journal of Biotechnology 6 (25), 286885.

17. Chunekar KC. Pandey G. Bhavaprakash Nighantu of Sri Bhavamisra. Chaukhambha Bharati Academy, Varanasi, 2010, pp 101.

18. Tripathi B. Charaka Samhita of Agnivesha Vol I. Chaukhamba Surbharati Prakashan, Varanasi, 2014,pp 91.

19. Srivastava S. Sharangadhara Samhita of Acharya Sharangadhara. 3rd ed. Chaukhambha Orientalia, Varanasi, 2003, pp 135.

20. Winter C A, Risley E A, Nuss G W. Carrageenin-induced edema in hind paw of the rat as an assay for antiinflammatory drugs. Proc. Soc. Exp. Biol. Med.1962; 111: 544-547.

21. Vogel HG. Drug Discovery and Evaluation. 2nd ed. Springer, pp 767.

22. Eddouks M, Chattopadhyay D, Zeggwagh NA. Animal Models as Tools to Investigate Antidiabetic and Anti-Inflammatory Plants. EvidenceBased Complementary and Alternative Medicine. 2012, 14.

23. Purnima, A., Koti B C, Tikare V P, Viswanathaswamy, A H M., Thippeswamy. Evaluation of Anti inflammatory Activity of Centratherum anthelminticum (L) Kuntze Seed. Indian J Pharm Sci. 2009; 72: 697-703.

24. Kunanusorn P, Teekachunhatean S, Sangdee C, Panthong A. Antinociceptive and anti-inflammatory activities of a Chinese Herbal Recipe (DJW) in animal models. International Journal of Applied Research in Natural Products. 2009; 12: 1-8.

25. Hulya Uzkeser, Elif Cadirci, Zekai Halici, Fehmi Odabasoglu, Beyzagul Polat, Tugba Nurcan Yuksel, Seda Ozaltin. Anti-inflammatory and antinociceptive effects of salbutamolon acute and chronic models of inflammation in rats: Involvement of antioxidant mechanism. Mediators of Inflammation. 2012:pp10.

26. Fischbach F T, Dunning M B. A Manual of Laboratory and Diagnostic tests. 8th ed. Wolters Kluwer, New Delhi, 2009, pp 642.

\section{HOW TO CITE THIS ARTICLE}

Solapure P, Pradeep, Mundugaru R, Hegde PL. Comparative anti-inflammatory activity of Clerodendrum serratum (Linn) Moon and Solanum xanthocarpum Schrad and Wendl in wistar ablino rats. The Journal of Phytopharmacology 2016;5(2):38-44. 